\title{
COMPARATIVE STUDY BETWEEN ENDOSCOPIC AND MICROSCOPIC TYMPANOPLASTY THROUGH TRANSCANAL APPROACH
}

\author{
By

\section{Mostafa Shams El-Din Khafagy, Hatem Salah El-Din El-Habashy, and Mahmoud Tarek Mohie El-Din El-Hamshary}

Otorhinolaryngology Department, Faculty of Medicine, Al-Azhar University

Email: mhmodelhamshary@gmail.com

\begin{abstract}
Background: Since the introduction of tympanoplasty in the 1950s, variety of surgical techniques has been developed for closure of tympanic membrane perforation. Tympanoplasty and myringoplasty are commonly used procedures for the treatment of chronic otitis media.

Objective: The aim of the present work was to compare the success rate between endoscopic and microscopic tympanoplasty through transcanal approach as regard improvement of hearing, closure of tympanic membrane perforation and the time of operation.

Patients and Methods: This prospective study was carried out on thirty patients who attended to outpatient clinic of Al-Hussien University Hospital from November 2018 to June 2019. All patients with the complaint of discharging ear and decreased hearing were screened. They were divided randomly into two equal groups; group A was treated by transcanal endoscopic tympanoplasty, and group B was treated by transcanal microscopic tympanoplasty. All operations were done at AL-Azhar University Hospitals (Al-Hussein University Hospital).

Results: The graft success rate was $80 \%$ in group A, and $73.3 \%$ in group B. There was significant improvement in hearing in both groups pre- and post - operatively, but the difference between both groups was not statistically significant. Microscopic tympanoplasty was shorter than endoscopic with no significant difference between both groups.

Conclusion: Tympanoplasty is an effective technique for recovering hearing thresholds secondary to a tympanic membrane perforation. In transcanal approach, postoperative cares were easy as the technique is minimally invasive in surgical approach, scar, bleeding and pain. The telescopic wide angle magnified view of the endoscope overcame most of the disadvantages of the microscope. Endoscopes provided good exposure of the tympanic membrane, usually without canaloplasty.
\end{abstract}

Keywords: Endoscopic, Microscopic Tympanoplasty, Transcanal Approach.

\section{INTRODUCTION}

Tympanoplasty involves eradication of the disease in the middle ear, repair of the perforated tympanic membrane and restoration of hearing. Endaural, transcanal and postauricular approaches are used during myringoplasty and tympanoplasty. Transcanal endoscopic approaches have become popular. The endoscopic approach provides a much larger field of view. When training interns, this view translates into a better visual image, as the middle ear and the ossicles can be visualized through the perforation. In the microscopic approach, 
a retroauricular approach is preferred for anterior perforations, while the endaural approach is preferred for posterior perforations, and small perforations are commonly treated using the transcanal approach (Halim and Borgstein, 2009; Onal et al., 2012 and Ayache, 2013).

Temporalis fascia is the most widely used materials with reported success rates of around $80 \%$ to $90 \%$ in patients who undergo primary tympanoplasty with a microscopic approach (Cavaliere et al., 2009).

Post auricular skin incisions are the most widely used approach for microscopic tympanoplasty. This conventional procedure results in surgical scar and significant pain to the patient. Minimally invasive otologic surgery has been developed along with endoscopic techniques (Wick et al., 2017).

Minimally invasive otologic surgery has been developed along with endoscopic techniques. Endoscopic ear surgery has become popular nowadays (Marchioni et al., 2010). Advantages of endoscopic ear surgery compared to the conventional microscopic surgery include avoiding endaural and postauricular incisions, minimal soft tissue dissection and angled view avoiding bone dissection (Ayache, 2013).

Transcanal approach is the most commonly used approach for endoscopic tympanoplasty. Endoscopic approach has resulted in decreased incidence of residual and recurrences during surgeries for cholesteatoma removal (Migirov et al., 2011).

The aim of the present work was to compare the success rate between endoscopic and microscopic tympanoplasty through transcanal approach as regard improvement of hearing, closure of tympanic membrane perforation and the time of operation.

\section{PATIENTS AND METHODS}

This prospective study was carried out on thirty patients who attended to outpatient clinic of Al-Hussien University Hospital from November 2018 to June 2019. All patients with the complaint of discharging ear and decreased hearing were screened. Those patients have tubotympanic type of chronic suppurative otitis media with small or medium sized perforation of pars tensa. All patients signed informed consents before the study.

Patients were divided randomly into two equal groups; group A treated by transcanal endoscopic tympanoplasty, and group B treated by transcanal microscopic tympanoplasty.

The exclusion criteria: patients refuse surgery or unfit for surgery

Traumatic perforation, neoplastic perforation, CSOM with cholesteatoma, recurrent perforation, subtotals or total perforation, marginal perforation and patients who required ossiculoplasty. Patients with ear discharge were initially treated conservatively and were included in the study when their ear became dry for at least 3monthes. 


\section{COMPARATIVE STUDY BETWEEN ENDOSCOPIC AND MICROSCOPIC...}

All patients were submitted to full history and general \& ENT examinations.

Investigations included: hearing evaluation and routine laboratory investigations (ESR, CBC, FBS, SGPT, S. creatinine, coagulation assay, $\mathrm{HCV}$ core antigen, HBVs antigen and ECG \&/or chest Xray if needed). Audiological assessment was done 3 months after surgery and analyzed. Tympanometry was done to assess postoperative middle ear ventilation.

\section{Statistical analysis:}

Recorded data were analyzed using the statistical package for social sciences, version 20.0 (SPSS Inc., Chicago, Illinois, USA). Quantitative data were expressed as mean \pm standard deviation (SD) and range. Qualitative data were expressed as frequency and percentage. The following tests were done:

- Independent-samples t-test of significance was used when comparing between two means.

- Paired sample t-test of significance was used when comparing between related sample.

- Chi-square (x2) test of significance was used in order to compare proportions between qualitative parameters.

- The confidence interval was set to $95 \%$ and the margin of error accepted was set to $5 \%$. Pvalue was considered significant when it was $<0.05$.

\section{RESULTS}

No statistically significant difference between both groups according to demographic data (table 1).

Table (1): Demographic data in both groups

\begin{tabular}{|c|c|c|c|}
\hline Demographicdata & $\begin{array}{c}\text { Group A: } \\
\text { Endoscopy }(n=15)\end{array}$ & $\begin{array}{l}\text { Group B: } \\
\text { Microscopy } \\
(\mathbf{n}=15)\end{array}$ & p-value \\
\hline \multicolumn{4}{|l|}{ Age (years) } \\
\hline Range & $11-48$ & $11-48$ & \multirow{2}{*}{0.635} \\
\hline Mean \pm SD & $30.68 \pm 5.83$ & $31.72 \pm 6.03$ & \\
\hline \multicolumn{4}{|l|}{ Sex } \\
\hline Male & $7(46.7 \%)$ & $5(33.3 \%)$ & \multirow{2}{*}{0.456} \\
\hline Female & $8(53.3 \%)$ & $10(66.7 \%)$ & \\
\hline \multicolumn{4}{|l|}{ Time of operation (min) } \\
\hline Range & $60-90$ & $50-80$ & \multirow{2}{*}{0.817} \\
\hline Mean \pm SD & $73.58 \pm 9.56$ & $72.80 \pm 8.74$ & \\
\hline
\end{tabular}

t-Independent Sample t-test; \#x2: Chi-square test

No statistically significant difference between both groups according to air bone gap (ABG) preoperatively and after 3 months postoperatively (Table 2 ). 
Table (2): Comparison between groups according to ABG

\begin{tabular}{|l|c|c|c|}
\hline ABG Groups & $\begin{array}{c}\text { Group A: Endoscopy } \\
(\mathbf{n = 1 5})\end{array}$ & $\begin{array}{c}\text { Group B: Microscopy } \\
(\mathbf{n}=15)\end{array}$ & \multirow{2}{*}{-value } \\
\cline { 1 - 3 } Preoperatively & & & \multirow{2}{*}{0.612} \\
\hline Range & $10-25$ & $10-25$ & \\
\hline Mean \pm SD & $19.23 \pm 5.67$ & $20.26 \pm 5.31$ & \multirow{2}{*}{0.464} \\
\hline After 3 months & & $5-30$ & \multirow{2}{*}{} \\
\cline { 1 - 3 } Range & $5-25$ & $13.39 \pm 7.23$ & \\
\cline { 1 - 3 } Mean \pm SD & $11.67 \pm 5.31$ & & \\
\cline { 1 - 3 }
\end{tabular}

Independent Sample t-test.

There was a statistically significant decrease in mean after 3 months compared to preoperatively according to $\mathrm{ABG}$ in

group (B), while it was highly significant statistically different in group (A) between pre and postoperative ABG (Table 3).

Table (3): Comparison between preoperatively and after 3 months post operatively according ABG in each group

\begin{tabular}{|l|c|c|}
\hline \multicolumn{1}{|c|}{ Groups } & $\begin{array}{c}\text { Group A: } \\
\text { Endoscopy }(\mathbf{n}=15)\end{array}$ & $\begin{array}{c}\text { Group B: } \\
\text { Microscopy (n=15) }\end{array}$ \\
\hline Preoperatively & $19.23 \pm 5.67$ & $20.26 \pm 5.31$ \\
\hline After 3 months of operation & $11.67 \pm 5.31$ & $13.39 \pm 7.23$ \\
\hline Mean Diff. \& (Change\%) & $7.56(39.31 \%)$ & $6.87(33.91 \%)$ \\
\hline p-value & $<0.001$ & 0.006 \\
\hline
\end{tabular}

No statistically significant difference between the studied groups as regard healing of perforation (Table 4).

Table 4: Comparison between group A: Endoscopy and Group B: Microscopy according to healing of perforation.

\begin{tabular}{|l|c|c|c|}
\hline \multicolumn{1}{|c|}{ Groups } & $\begin{array}{c}\text { Group A: } \\
\text { Endoscopy (n=15) }\end{array}$ & $\begin{array}{c}\text { Group B: } \\
\text { Microscopy (n=15) }\end{array}$ & p-value \\
\hline Completely healed & $13(86.7 \%)$ & $12(80.0 \%)$ & \multirow{2}{*}{0.624} \\
\hline $\begin{array}{l}\text { Residual } \\
\text { perforation }\end{array}$ & $2(13.3 \%)$ & $3(20.0 \%)$ & \\
\hline
\end{tabular}

No statistically significant difference between group A and group B according to failure and success of surgery (Table 5).

Table (5): Comparison between group A: Endoscopy and group B: Microscopy according to improvement (successful operatipon).

\begin{tabular}{|c|c|c|c|}
\hline $\begin{array}{ll}\text { Failure } & \text { Groups } \\
\end{array}$ & $\begin{array}{c}\text { Group 1: } \\
\text { Endoscopy }(n=15)\end{array}$ & $\begin{array}{c}\text { Group 2: } \\
\text { Microscopy }(n=15)\end{array}$ & p-value \\
\hline Failure & $3(20 \%)$ & $4(26.7 \%)$ & \multirow[b]{2}{*}{0.666} \\
\hline $\begin{array}{l}\text { No failure } \\
\text { (successful) }\end{array}$ & $12(80 \%)$ & $11(73.3 \%)$ & \\
\hline
\end{tabular}

x2-Chi-square test. 


\section{COMPARATIVE STUDY BETWEEN ENDOSCOPIC AND MICROSCOPIC...}

\section{DISCUSSION}

Our study, of the 30 patients, 15 underwent transcanal endoscopic tympanoplasty. (Group A) and 15 underwent underwent transcanal microscopic tympanoplasty (Group B). The groups were comparable with respect to age and sex. As regard age, no statistically significant difference between two groups. Salam et al. (2018) gave the same result. As regard sex in our study, no statistically significant difference between two groups. It is consistent with the study of Lade et al. (2014) and Salam et al. (2018).

The duration of the operation in our study showed no significant difference in the mean time of the two groups. This was found to be agreed with study of Tan et al. (2016) and Salam et al. (2018) but the results of the previous studies was found to be of statistically significant difference. There were other studies denoting that the endoscopic technique is shorter than the microscopic one, like Patel et al. (2015), Huang et al. (2016) and Choi et al. (2017).

This difference in results from our study may be due to avoiding the postauricular incision, soft tissue dissection, and wound closure in transcanal approach. In our study, microscopic tympanoplasty was shorter than endoscopic because of its major advantages over the endoscope which provided binocular vision and the doublehanded technique.

Postoperative hearing gain is an important indicator of treatment success in patients who have undergone tympanoplasty these results showed significant postoperative hearing improvement, while there was no significant difference in the postoperative (A.B GAP) between both groups. In comparison to our study, many studies have reported successful results regarding postoperative hearing gain in patients as in study of Yadav et al. (2009), Friedman et al. (2013), Yilmaz et al. (2015), Migirov \& Wolf (2015), Huang et al. (2016), Sinha et al. (2017) and Salam et al. (2018).

Healing of the perforation in our study showed no significant difference in the graft take rate between two groups. In comparison to our study, many studies have reported successful results regarding healing of the perforation as in study of Yadav et al. (2009), Furukawa (2014), Migirov and Wolf (2015), Huang et al. (2016), Tan et al. (2016) and Salam et al. (2018).

Success of the operation, in this study, it was considered to be "successful" as there were complete healing of the tympanic membrane and improvement of hearing postoperatively,i.e. decrease in the $A B G$,it was found to be statistically insignificant. It is consistent with study of Ayache (2013), Özgür et al. (2015) and Patel et al. (2015). Patel et al. (2015) also reported that the major disadvantage of endoscopic approach was the necessity to operate with a single hand. They also stated that any bleeding in the external ear canal made manipulations very difficult and underlined the necessity to achieve total hemostasis in the external ear canal.

\section{CONCLUSION}

The success rate of endoscope assisted myringoplasty was comparable to that of microscope assisted myringplasty through transcanal approach in both groups. Shortterm outcomes of both techniques were 
good and there was no significant difference between their graft uptake and audiometric results. Good tympanoplasty procedure carried more significance in success of surgery than the type of technique preferred during the surgery.

\section{REFERENCES}

1. Ayache, S. (2013): Cartilaginous myringoplasty: the endoscopic transcanal procedure. European Archives of Oto-RhinoLaryngology, 270(3): 853-860.

2. Cavaliere, M., Mottola, G., Rondinelli, M. and Iemma, M. (2009): Tragal cartilage in tympanoplasty: anatomic and functional results in 306 cases. Acta Otorhinolaryngologica Italica, 29(1): 27-32.

3. Choi, N., Noh, Y., Park, W., Lee, J. J., Yook, S., Choi, J. E. and Moon, I. J. (2017): Comparison of endoscopic tympanoplasty to microscopic tympanoplasty. Clinical and experimental otorhinolaryngology, 10(1),: 44-49.

4. Friedman, A. B., Gluth, M. B., Moore, P. C. and Dornhoffer, J. L. (2013): Outcomes of cartilage tympanoplasty in the pediatric population. Otolaryngology--Head and Neck Surgery, 148(2): 297-301.

5. Furukawa, T., Watanabe, T., Ito, T., Kubota, T. and Kakehata, S. (2014): Feasibility and advantages of transcanal endoscopic myringoplasty. Otology \& Neurotology, 35(4): e140-e145.

6. Halim, A. and Borgstein, J. (2009): Pediatric myringoplasty: postaural versus transmeatal approach. International journal of pediatric otorhinolaryngology, 73(11): 15801583.

7. Huang, T. Y., Ho, K. Y., Wang, L. F., Chien, C. Y. and Wang, H. M. (2016): A comparative study of endoscopic and microscopic approach type 1 tympanoplasty for simple chronic otitis media. J Int Adv Otol, 12(1): 28-31.

8. Lade, H., Choudhary, S. R. and Vashishth, A. (2014): Endoscopic vs microscopic myringoplasty: a different perspective.
European Archives of Oto-RhinoLaryngology, 271(7): 1897-1902.

9. Marchioni, D., Alicandri- Ciufelli, M., Piccinini, A., Genovese, E. and Presutti, L. (2010): Inferior retrotympanum revisited: an endoscopic anatomic study. The Laryngoscope, 120(9): 1880-1886.

10. Migirov, L. and Wolf, M. (2015): Transcanal microscope-assisted endoscopic myringoplasty in children. BMC Pediatrics, 15(1): 32-49.

11. Migirov, L., Shapira, Y., Horowitz, Z. and Wolf, M. (2011): Exclusive endoscopic ear surgery for acquired cholesteatoma: preliminary results. Otology \& Neurotology, 32(3): 433-436.

12. Onal, K., Arslanoglu, S., Songu, M., Demiray, U. and Demirpehlivan, I. A. (2012): Functional results of temporalis fascia versus cartilage tympanoplasty in patients with bilateral chronic otitis media. The Journal of Laryngology \& Otology, 126(1): 22-25.

13. Özgür, A., Dursun, E., Erdivanli, Ö. Ç., Coşkun, Z. Ö., Terzi, S., Emiroğlu, G. Ö. K. H. A. N. and Demirci, M. (2015): Endoscopic cartilage tympanoplasty in chronic otitis media. The Journal of Laryngology \& Otology, 129(11): 10731077.

14. Patel, J., Aiyer, R. G., Gajjar, Y., Gupta, R., Raval, J. and Suthar, P. P. (2015): Endoscopic tympanoplasty vs microscopic tympanoplasty in tubotympanic CSOM: a comparative study of 44 cases. Int J Res Med Sci, 3(8): 1953-1957.

15. Salam RTA, Nambiar SS and Anusha V. (2018): Comparative Study of the Outcomes of Tympanoplasty by the Conventional Microscopic and Endoscopic Techniques. Int J Sci Stud.,6(9) :81-86

16. Sinha, M., Hirani, N. and Khilnani, A. K. (2017): Comparison of endoscopic underlay and microscopic underlay tympanoplasty: a prospective research at a tertiary care centre in Gujarat. International Journal of 
Otorhinolaryngology and Head and Neck Surgery, 3(4): 874.

17. Tan, H. E., Santa Maria, P. L., Eikelboom, R. H., Anandacoomaraswamy, K. S. and Atlas, M. D. (2016): Type I tympanoplasty meta-analysis: a single variable analysis. Otology \& Neurotology, 37(7): 838-846.

18. Wick, C. C., Arnaoutakis, D., Barnett, S. L., Rivas, A. and Isaacson, B. (2017): Endoscopic transcanal transpromontorial approach for vestibular schwannoma resection: a case series. Otology \& Neurotology, 38(10): e490-e494.
19. Yadav, S. P., Aggarwal, N., Julaha, M. and Goel, A. (2009): Endoscope-assisted myringoplasty. Singapore medical journal, 50(5): 510-512.

20. Yilmaz, M. S., Guven, M., Kayabasoglu, G. and Varli, A. F. (2015): Comparison of the anatomic and hearing outcomes of cartilage type 1 tympanoplasty in pediatric and adult patients. European Archives of Oto-RhinoLaryngology, 272(3): 557-562. 


\section{در اسة مقارنة لترقيع طبلة الأذن باستخدام المنظار و استخدام

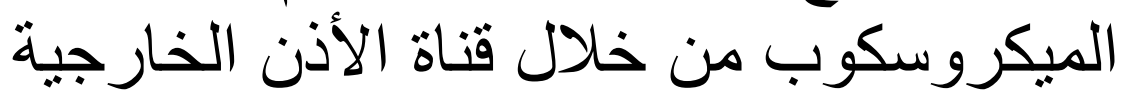

مصطفي شمس الدين خفاجي، حاتم صلاح الدين الحبشي، محمود طارق محي الدين الهمشري

\section{قسم الأنن والأنف والحنجرة، كلية طب الأزهر}

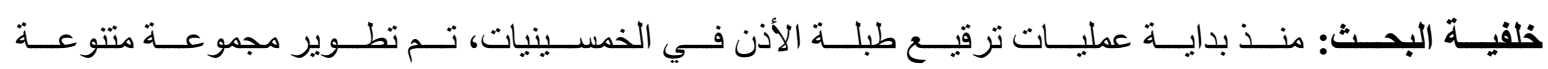

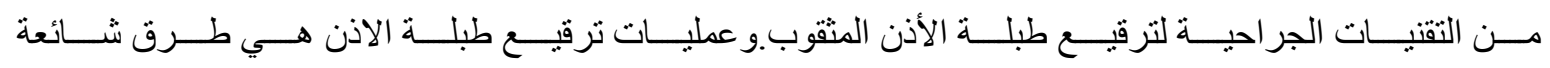
لعلاج التهابات الأذن الوسطي المزمنة.

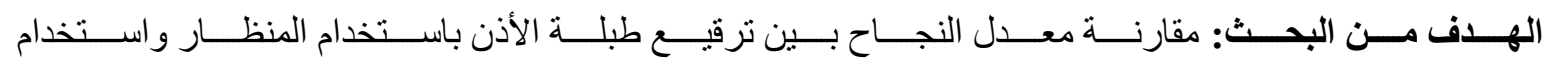

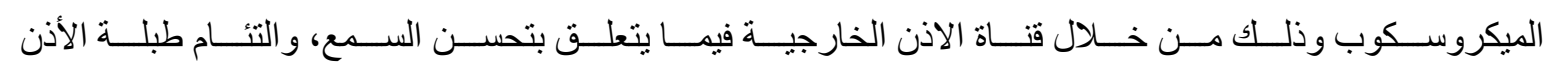
وأيضا مدة العملية.

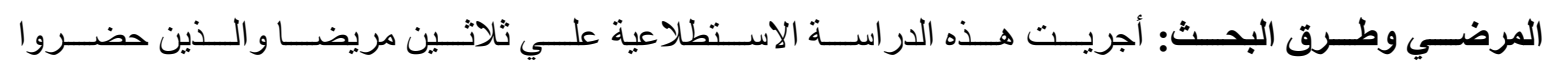

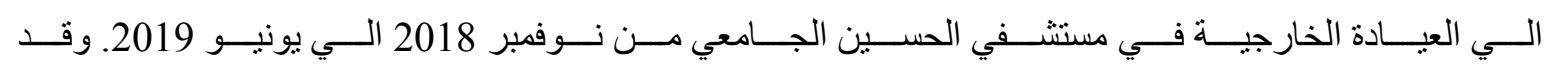

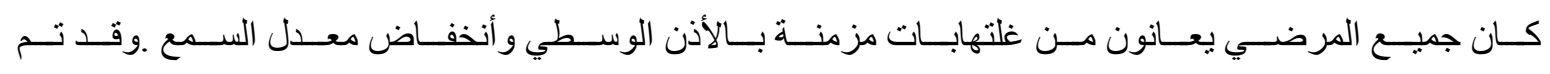

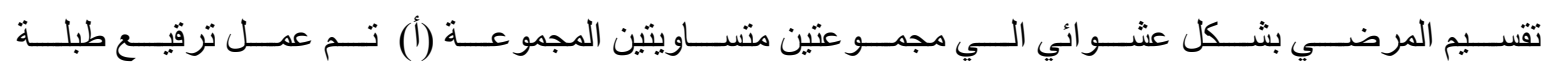
الأذن باستخدام المنظار و المجموعة (ب) تم عمل ترقيع طبلة الأذن باستخدام الميكروسكوب.

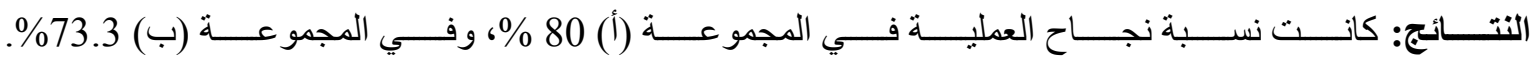

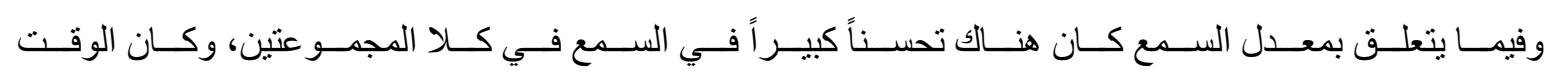

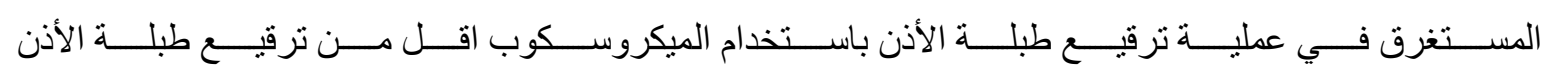
باستخدام المنظار ولكن لم يكن هناك فرقاً احصائياً ما بين المجمو عتين.

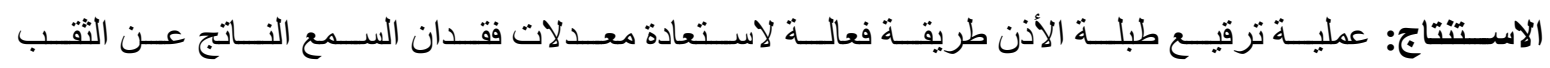

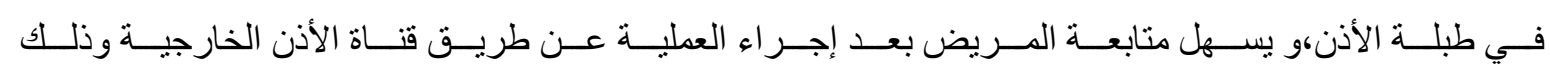

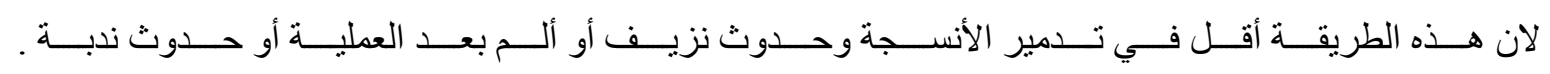

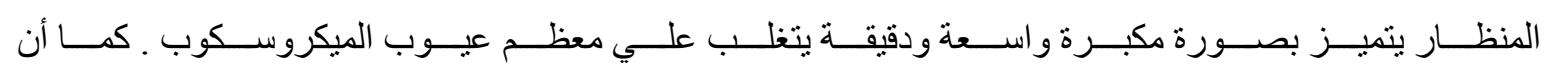

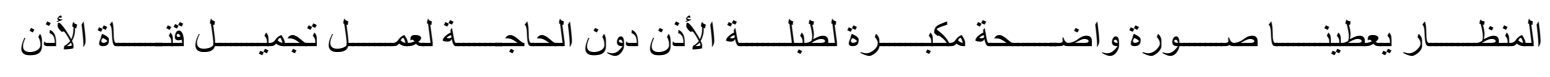
الخارجية. 